\title{
Search for evidence of a viral aetiology for inflammatory bowel disease
}

\author{
H H YOSHIMURA, M K ESTES, AND D Y GRAHAM \\ From the Digestive Disease Section, Departments of Medicine and Virology, Veterans Administration \\ Medical Center, and Baylor College of Medicine, Houston, Texas, USA
}

SUMmary The aetiology of the inflammatory bowel diseases, Crohn's disease, and ulcerative colitis, is still obscure. A viral aetiology has been proposed, based in part on reports that filtrates prepared from tissues of patients with inflammatory bowel disease induce cytopathic effects in tissue culture cells. Our attempts to culture viruses in many cell lines from filtrates prepared from the tissue of 95 patients have been negative, except for one case in which cytomegalovirus was isolated from the tissue of a Crohn's disease patient. Our studies confirm previous reports that intestinal tissue filtrates induce cytopathic effects in inoculated cell cultures, but the effect we observed is non-specific; cytopathic effects were induced in most cell lines tested and with similar frequency irrespective of whether the intestinal filtrates were prepared from Crohn's disease patients, ulcerative colitis patients, or non-inflammatory bowel disease controls. Electron microscopy studies of tissue culture cells exhibiting cytopathic effects have not revealed virus particles. Characterisation of the cytopathic effect inducing factor showed that it was incapable of serial passage in tissue culture, too small to be a conventional virus, resistant to inactivation by ultraviolet light, and heat stable. Our results suggest that the observed cytopathic effect was caused by a non-replicating cytotoxic factor, or factors, released from intestinal tissues of both inflammatory bowel disease and non-inflammatory bowel disease patients.

The aetiology of Crohn's disease and of another chronic inflammatory bowel disease, ulcerative colitis, remains unknown. ${ }^{1}$ Published reports have suggested an infectious basis for these diseases, and a number of agents have been proposed, including conventional bacteria, cell wall defective bacteria, and viruses. ${ }^{2}$ Studies supporting a causative role for any of these agents, however, have been unconvincing and irreproducible.

The evidence suggesting a viral aetiology for Crohn's disease and ulcerative colitis has included demonstration of the ability of tissue homogenates to induce cytopathic effects in tissue culture cells. ${ }^{34}$ A viral nature for the cytopathic effect of inducing agents has been proposed based on the ability to serially pass the cytopathic effects, on the ability of hyperimmune guinea pig antisera prepared against the purported Crohn's disease and ulcerative colitis agents to inhibit production of the cytopathic

Address for correspondence: David Y Graham. MD. Room 612, Bldg 1A Veterans Administration Medical Center, 2002 Holcombe Blvd, Houston. TX 77211. USA.

Received for publication 22 July 1983 effects, and on the identification of virus like particles by electron microscopic analysis of infected tissue culture samples. These observations have not been confirmed; no virus has been conclusively identified. In fact, a recent paper from the same laboratory reported that the 'early cytopathic effects' observed in some cell lines was caused by cytotoxins. 5

This paper describes our efforts to identify viruses in the tissues of inflammatory bowel disease patients. Our results suggest that while cytopathic effects can be induced in tissue culture cells inoculated with filtrates of intestinal tissues, the cytopathic effect observed is caused by nonreplicating cytotoxic factor(s) that could be released from intestinal tissues of both inflammatory bowel disease and non-inflammatory bowel disease patients rather than by a conventional virus.

\section{Methods}

TISSUE CULTURE

Many tissue culture systems have been used in our 
studies (Table 1). Although there were minor variations in working with some cell lines, cells were generally grown as monolayers in Eagle's minimal essential medium supplemented with antibiotics (100 U/ml penicillin, $100 \mu \mathrm{g} / \mathrm{ml}$ streptomycin), fetal bovine serum $(5-10 \%)$, and sodium bicarbonate $(0.075 \%)$ at $37^{\circ} \mathrm{C}$ in a humidified incubator containing an atmosphere of $5 \% \mathrm{CO}_{2}$ in air.

\section{CHICK EMBRYO FIBROBLAST CULTURES}

Chick embryo cells were either obtained as cell suspensions from SPAFAS, Inc (Norwich, CT) at concentrations of $15-30 \times 10^{6} \mathrm{cells} / \mathrm{ml}$ or prepared in our laboratory from embryonated eggs (SPAFAS Inc) by the procedure described by Vogt. ${ }^{6}$ Cells were passed by treatment with $0.125 \%$ trypsin and $0.2 \mathrm{mg} / \mathrm{ml}$ EDTA in Ca-, $\mathrm{Mg}$-free Hanks' buffered salt solution. ${ }^{7}$ Susceptible primary cells were aliquotted and stored frozen (liquid nitrogen) in growth medium containing $10 \%$ dimethylsulphoxide; such cells were seeded directly for experiments as cells passaged further lost sensitivity to the cytopathic effect inducing factor.

\section{PATIENTS' TISSUES}

In the course of these studies, tissues obtained from 95 patients were examined. These patients, who underwent surgery at cooperating institutions in the Houston, Texas, area, included 57 Crohn's disease patients, 15 ulcerative colitis patients, and 23

Table 1 Cells tested for cytopathic effect induction by filtrates of human intestinal tissues

\begin{tabular}{ll}
\hline Cell type & Cell line \\
\hline Human embryonic lung & M7 \\
& WI38 \\
& MRC5 \\
& HEL638 \\
Human intestine & HEL670 \\
& FHS74 \\
Human rectal tumour & FHS677 \\
Human embryonic kidney & HRT-18 \\
Monkey kidney & HEK \\
& MK2 \\
& RMK \\
Canine kidney & MA-104 \\
Feline kidney & MDCK \\
Rabbit kidney* & CRFK \\
Rabbit ileum* & \\
Mouse adrenal tumour & \\
Chick embryo fibroblasts ${ }^{*}$ & Y-1
\end{tabular}

* Primary cultures.

† In a few cases, cultures were started from cell suspensions obtained from commercial sources; in most cases, cultures were prepared in our laboratory from embryonated eggs by procedures described in 'Methods". non-inflammatory bowel disease controls. The controls included 10 patients with carcinoma, three with infarcted bowel, two with diverticulosis, and one each with diverticulitis, Meckel's diverticulum, oesophageal varices, and colon polyps, as well as four normal patients (three trauma patients and one patient who underwent an ileojejunal bypass operation).

\section{PREPARATION OF TISSUE FILTRATES}

Three methods of tissue filtrate preparation were used. The first was similar to that described by Whorwell et al. ${ }^{8}$ Immediately upon receipt, tissues were trimmed of fat, weighed, washed with Hanks' buffered salt solution, and then stored at $-70^{\circ} \mathrm{C}$. After thawing, a $20 \%$ suspension of the tissue in Hanks' buffered salt solution was minced, an equal volume of Genetron (trichloro-trifluoroethane, DuPont Co, Wilmington, DE) was added, and the entire mixture was homogenised four times for 30 seconds each in a Sorvall Omni-Mixer (Newtown, CT). After centrifugation for 10 minutes at $750 \mathrm{~g}$, the aqueous layer was removed. The Genetron layer was re-extracted, and the combined aqueous layers were then filtered successively through AP25, 5.0 $\mu \mathrm{m}, 1.2 \mu \mathrm{m}, 450 \mathrm{~nm}$, and $220 \mathrm{~nm}$ filters (Millipore, Bedford, MA).

The other two methods of filtrate preparation generally followed the procedure of Gitnick et al, ${ }^{4}$ differing primarily in the initial processing of the tissues. In one method, tissues were trimmed, weighed, and washed with Hanks' buffered salt solution before storage at $-70^{\circ} \mathrm{C}$. After thawing, tissue segments were minced in Hanks' buffered salt solution, and then washed 10 times in Hanks' buffered salt solution. After each wash, tissue pieces were pelleted by centrifuging for 10 minutes at $600 \mathrm{~g}$ at $4^{\circ} \mathrm{C}$. The final pellet was resuspended in 4 volumes of Hanks' buffered salt solution, and homogenised for one minute in a Sorvall OmniMixer. The suspension was then sonicated (Heat Systems-Ultrasonics Inc, Plainview, NY) and centrifuged for 30 minutes at $600 \mathrm{~g}$. The supernate was finally filtered successively through Whatman no 2 filter paper (Clifton, NJ) and $450 \mathrm{~nm}$ and $200 \mathrm{~nm}$ Nalgene (Nalge Co, Rochester, NY) filter units. The resulting filtrates were aliquotted and stored at $-70^{\circ} \mathrm{C}$.

The final procedure, which was developed after a visit to Dr Gitnick's laboratory, was designed to more faithfully reproduce his methods. In this method, the tissue was minced and thoroughly washed before being frozen. The fresh tissue was first rinsed in Hanks' buffered salt solution containing penicillin and streptomycin to remove faecal material. About $10 \mathrm{~g}$ of tissue were then 
minced in a specimen cup containing approximately $70 \mathrm{ml}$ Hanks' buffered salt solution, and the pieces were washed at least 10 times in Hanks' buffered salt solution. The wash solution was poured off at each washing after covering the specimen cup with gauze. When the supernate was clear, it was poured off and the volume of packed minced tissue recorded before freezing at $-70^{\circ} \mathrm{C}$. For further processing, the tissue was thawed, saline was added to yield a $20 \%$ suspension of the minced tissue, and the suspension was then homogenised for 15 minutes. The samples were centrifuged for 20 minutes at $600 \mathrm{~g}$, and the supernatants were successively filtered through two thicknesses of Whatman no 1 paper, two thicknesses of Whatman no 5 paper, and $800 \mathrm{~nm}, 450 \mathrm{~nm}$, and $200 \mathrm{~nm}$ Nalgene filter units.

All filtrates were frozen in small $(1-2 \mathrm{ml})$ aliquots so that multiple experiments on each sample could be performed without repeatedly freezing and thawing the inocula.

\section{INOCULATION OF CHICK EMBRYO FIBROBLAST}

\section{CULTURES}

Suspensions of $10^{6}$ cells in $2 \mathrm{ml}$ of medium (Eagle's minimal essential medium supplemented with $20 \%$ heat-inactivated fetal bovine serum, $1 \%$ glutamine, $250 \mathrm{U} / \mathrm{ml}$ penicillin, and $250 \mu \mathrm{g} / \mathrm{ml}$ streptomycin) were dispensed into $16 \times 125 \mathrm{~mm}$ culture tubes (Kimble, Vineland, NJ). After the cells attached, the medium was changed to Eagle's minimal essential medium supplemented with $5 \%$ heat inactivated fetal bovine serum, glutamine, and antibiotics. Before inoculation, the medium on the cultures was changed to Eagle's minimal essential medium supplemented with $1 \%$ fetal bovine serum. The sample was then added directly to the culture medium. In general, $0.2 \mathrm{ml}$ of inoculum were added per tube, but this was sometimes increased to 0.5 $\mathrm{ml}$. In a few experiments, the medium was removed from the tubes, the inoculum was added, and adsorption of any virus present was allowed to proceed for one hour at $37^{\circ} \mathrm{C}$, after which fresh medium was added to the tube. Cultures were incubated at $37^{\circ} \mathrm{C}$ in a humidified $5 \% \mathrm{CO}_{2}$ incubator and observed daily for the development of cytopathic effects. The medium was changed when it turned acidic, generally four days after inoculation. The cells started to deteriorate at about seven days after inoculation and could be observed for no more than 11 days after inoculation.

\section{ELECTRON MICROSCOPY}

Chick embryo fibroblasts were grown on $35 \mathrm{~mm}$ tissue culture dishes and inoculated with tissue filtrates or mock-infected with Hanks' buffered salt solution. When cytopathic effect was evident, cells were fixed in situ in 3\% glutaraldehyde buffered with $0 \cdot 1 \mathrm{M}$ PIPES [piperazine-N, $\mathrm{N}^{\prime}$-bis(2ethanesulphonic acid)], postfixed with $2 \%$ osmium tetroxide in $0 \cdot 1 \mathrm{M}$ PIPES, $\mathrm{pH} 7 \cdot 4$, stained en bloc with $2 \%$ uranyl acetate, and dehydrated in a graded ethanol series. After embedding in Epon, involved and normal areas were identified, cut out, and mounted onto resin blocks made in Beem capsules. Thin sections were cut on a Porter-Blum MT-2 microtome (Sorvall Instruments), poststained with lead citrate, and examined with an RCA EMU-3F electron microscope operated at $100 \mathrm{kV}$.

\section{ANIMAL TRANSMISSION STUDIES}

Tissue filtrates from inflammatory bowel disease patients and controls were prepared by either the first or second method described above. Male New Zealand white rabbits 8-12 weeks of age were treated to eliminate intestinal parasites before inoculation with the tissue filtrates, and continual surveillance was maintained to ensure that the rabbits remained free of parasites. Laparotomy was performed on 30 animals and $2.0 \mathrm{ml}$ or $5 \mathrm{ml}$ of tissue filtrates (given in 0.1 or $0.2 \mathrm{ml}$ portions at multiple sites) were inoculated into the wall of the distal ileum. Fifteen animals received $0.5 \mathrm{ml}$ or $5 \mathrm{ml}$ of tissue filtrates in ear veins. Periodically, all rabbits were weighed and blood samples were drawn. Eight to 15 months after inoculation, they were killed and gross and microscopic analyses were performed by a pathologist.

\section{IMMUNOFLUORESCENCE TESTS FOR}

CYTOMEGALOVIRUS

Human embryonic lung cells were grown on circular $15 \mathrm{~mm}$ glass cover slips in $60 \mathrm{~mm}$ tissue culture dishes. The cells were inoculated by transferring the cover slips to new dishes, adding 25-100 $\mu$ l of inoculum, incubating for one hour at $37^{\circ} \mathrm{C}$, then flooding the cover slips by adding $5 \mathrm{ml}$ of medium. When cytopathic effect was observed, the medium was removed, and the cultures were washed with tris buffered saline, fixed in ethanol for 10 minutes at $-20^{\circ} \mathrm{C}$, and air-dried.

For staining, the coverslips were moistened by dipping in tris buffered saline, and $25 \mu \mathrm{l}$ of FITC conjugated goat anti-cytomegalovirus serum was added for a 30 minute incubation at $37^{\circ} \mathrm{C}$ in a moist chamber. The coverslips were washed three times in tris buffered saline, rinsed in distilled water, mounted in Elvanol, and examined in a Zeiss fluorescent microscope equipped for epifluorescence. 
Results

INITIAL TESTING OF CELL LINES FOR SENSITIVITY TO CYTOPATHIC EFFECT INDUCING FACTORS

Since 1978, we have tested 18 tissue culture cell lines for susceptibility to cytopathic effect inducing factors in filtrates of human intestinal tissues (Table 1). Initial studies involved filtrates from 64 tissues prepared by either the first or second methods described earlier in this paper. In a majority of the cell lines tested with these initial filtrates, cytopathic effects were either not detectable or very subtle. Furthermore, there was no correlation between patient group (Crohn's disease, ulcerative colitis, non-inflammatory bowel disease controls) and the presence or absence of cytopathic effects. Attempts to pass cytopathic effect inducing agents in cell cultures following freeze-thawing and sonication of cells that exhibited cytopathic effects were not successful. Similarly, blind passage of cultures that did not exhibit cytopathic effects yielded no evidence of the presence of an infectious agent. A virus was recovered in only one experiment in which inoculation of HEL 638 cells with a tissue filtrate from a Crohn's disease patient yielded striking cytopathic effect which was observed through four passages in tissue culture. The cytopathic effect was characteristic of that caused by cytomegalovirus, and electron microscopy revealed herpes virus like particles in inoculated tissue cultures. Immunofluorescence tests confirmed the presence of cytomegalovirus. Positive controls of cytomegalovirus infected cells and negative controls of uninoculated HEL cells and HEL cells inoculated with herpes simplex virus, types 1 and 2 , were included in these analyses.

CYTOPATHIC EFFECTS IN CHICK EMBRYO

FIBROBLAST CULTURES

While we were carrying out the studies summarised above, Gitnick and his associates reported the production of cytopathic effects in chick embryo fibroblasts by tissue filtrates from inflammatory bowel disease patients. We confirmed that these cells were very useful because of their high sensitivity, ready availability, and production of strong cytopathic effects. We evaluated the cytopathic effect producing ability of intestinal filtrates in chick embryo fibroblasts either obtained from SPAFAS Inc or prepared from embryonated eggs in our own laboratory. Although some myotubes, which can be eliminated by passage, were seen in our chick embryo fibroblast cultures and not in SPAFAS cell suspensions, the source of the cells did not cause any differences in more important properties such as cell longevity or sensitivity to cytopathic effect producing agents. All cell preparations showed reduced sensitivity to cytopathic effect inducing agents on passage.

Cytopathic effect was observed in chick embryo fibroblast cultures within three days after inoculation with filtrates of tissues prepared from Crohn's disease, ulcerative colitis, and noninflammatory bowel disease controls by the second and third procedures described previously. Cytopathic effect was characterised by cell rounding, clumping, a grainy appearance to the cells, and in some cases, vacuolation. In addition, myotubes disappeared if they had been present in the culture before inoculation (Figure). Two types of cytopathic effect were observed, one characterised by foci of rounded, clumped cells (Fig. c) and the other by clumped cells forming ridges (Fig. d). The type of cytopathic effect did not correlate with any patient group (Crohn's disease, ulcerative colitis, or non-inflammatory bowel disease controls). Fifteen of 21 Crohn's disease specimens $(71 \%)$, eight of 10 ulcerative colitis specimens $(80 \%)$, and four of six non-inflammatory bowel disease control specimens (67\%) yielded cytopathic effects at least once when inoculated into chick embryo fibroblast cultures (Tables 2 and 3).

Once a sensitive assay system that would reproducibly produce cytopathic effects was established, we designed experiments to characterise the cytopathic effect producing agent. Our strategy included: (1) passage of the agent in tissue culture; (2) diluting the sample; (3) treatment of the sample with ultraviolet light, which would inactivate all but a few very unusual infectious agents - for example, scrapie agent; (4) treatment of the filtrates with Genetron, which would remove lipid and inactivate enveloped viruses; (5) centrifugation at speeds sufficient to pellet all known viral agents; (6) heating. For these experiments, samples available in large quantities were tested. In particular, samples 213 and 218 , each of which strongly induced one of the two characteristic types of cytopathic effect described above, were characterised. In addition, sample 214, which did not normally induce cytopathic effects, was analysed as a control to monitor for new cytopathic factors that might appear after any particular treatment.

\section{ATTEMPTS TO PASS THE CYTOPATHIC EFFECT} INDUCING AGENT IN TISSUE CULTURE

A variety of methods for passing infectious agents in primary chick embryo fibroblast cultures were tested. As no method appeared to be clearly superior (data not shown), we chose freeze-thawing and sonication for further experiments as it is generally regarded as the most efficient method of 

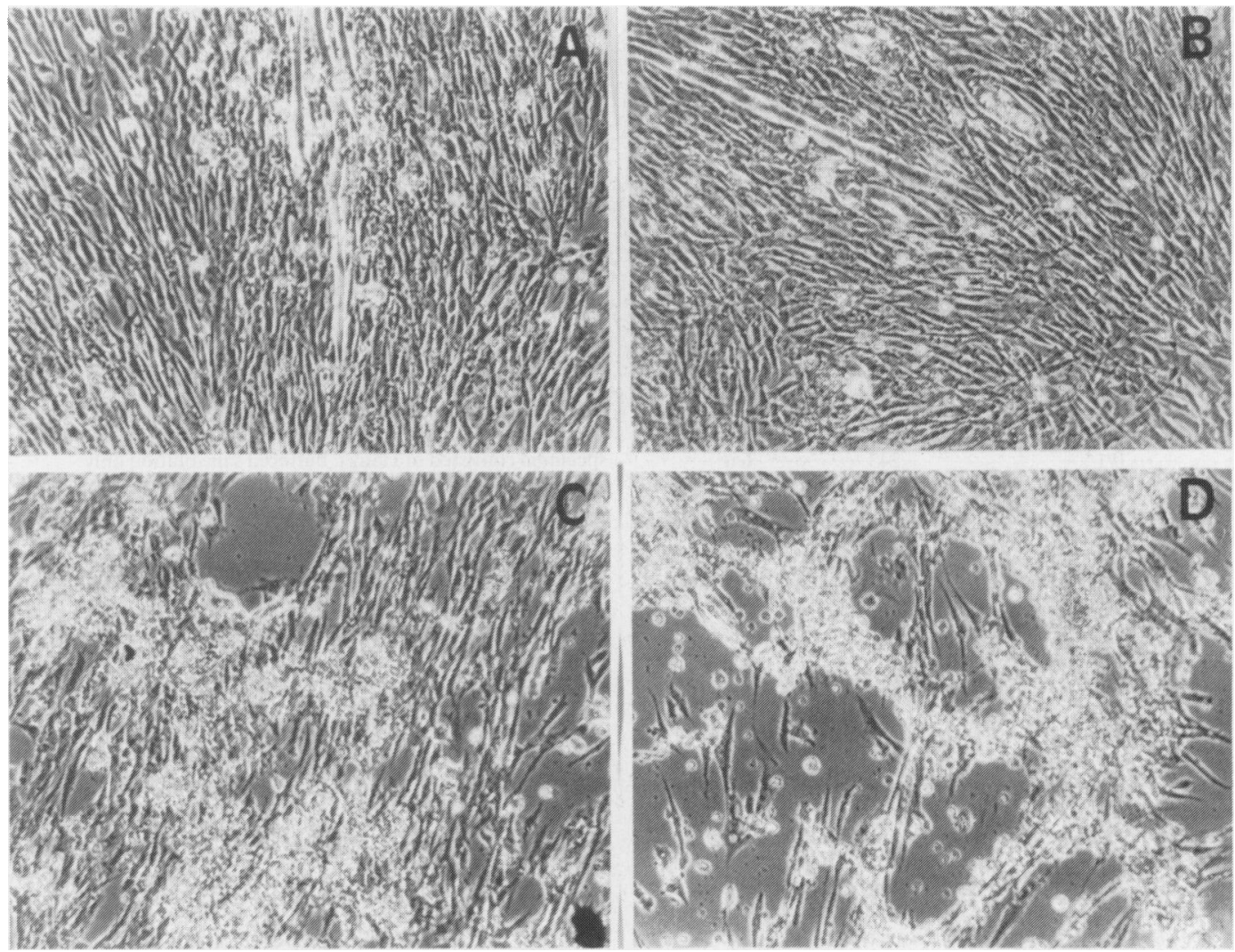

Figure Appearance of cytopathic effects in chick embryo fibroblast cultures after inoculation with intestinal tissue filtrates. (a) Uninoculated control, exhibiting regular monolayer and myotube formation. (b) Inoculated with filtrate from Crohn's disease specimen 189, which never produced cytopathic effects; note presence of myotube. (c) Inoculated with filtrate from Crohn's disease specimen 213, exhibiting rounding and clumping of cells typical of cytopathic effects observed with this specimen. (d) Inoculated with filtrate from non-inflammatory bowel disease control specimen 218; cell rounding and clumping into ridges characteristic of cultures inoculated with this sample can be seen.

transferring potentially infectious agents regardless of their localisation within the culture or their possible tight association with cell structures. When passage of cytopathic effect inducing factors was attempted with specimens that yielded strong cytopathic effects on initial passage, cytopathic effect producing ability diminished with passage and was completely lost within two passages (Table 4). Each passage was carried out with fresh cultures of primary chick embryo fibroblasts and each experiment included parallel control cultures inoculated with unpassaged filtrates to reveal any loss of sensitivity in the cells. In all experiments, the chick embryo fibroblast cells were sensitive to the unpassaged filtrates, but not to the passaged materials.
CHARACTERISATION OF THE CYTOPATHIC EFFECT

INDUCING AGENT

The cytopathic effect inducing agent was completely resistant to ultraviolet light (Table 5) whereas the control virus (simian rotavirus SA11) lost greater than $99.99 \%$ of infectivity with similar treatment $(30$ minutes at a distance of $13.7 \mathrm{~cm}$ ). Genetron extraction was performed by thoroughly mixing a $0.6 \mathrm{ml}$ aliquot of filtrate with $0.6 \mathrm{ml}$ of Genetron and centrifuging for 10 minutes at $400 \mathrm{~g}$; the aqueous layer was tested for cytopathic effect inducing capability. There was a slight reduction in cytopathic effect inducing ability after Genetron extraction. Heat treatment $\left(56^{\circ} \mathrm{C}\right.$ in a water bath for one hour) increased the extent of cytopathic effect; this is apparently owing to a new cytopathic factor 
Table 2 Detection in chick embryo fibroblast cultures of cytopathic effect inducing agents in filtrates of intestinal tissues from inflammatory bowel disease patients

\begin{tabular}{|c|c|c|c|}
\hline \multicolumn{2}{|c|}{ Crohn's disease } & \multicolumn{2}{|c|}{ Ulcerative colitis } \\
\hline Specimen* & $\begin{array}{l}\text { No pos/ } \\
\text { no tested }\end{array}$ & Specimen & $\begin{array}{l}\text { No pos/ } \\
\text { no tested }\end{array}$ \\
\hline $156 \mathrm{UCLA}$ & $5 / 5$ & 202 UCLA & $3 / 4$ \\
\hline 174 & $3 / 3$ & 184 & $1 / 4$ \\
\hline 187 & $1 / 3$ & 183 & $2 / 2$ \\
\hline 189 & $0 / 5$ & 214 & $0 / 12$ \\
\hline 193 & $2 / 3$ & 215 & $0 / 4$ \\
\hline 199 & $4 / 4$ & 221 & $5 / 7$ \\
\hline 201 & $0 / 3$ & 231 & $2 / 8$ \\
\hline 203 & $0 / 3$ & 232 & $5 / 5$ \\
\hline 206 & $0 / 1$ & 243 & $6 / 6$ \\
\hline 212 & $13 / 13$ & & \\
\hline 213 & $18 / 18$ & & \\
\hline $213 \mathrm{~A} \ddagger$ & $4 / 4$ & & \\
\hline 216 & $5 / 6$ & & \\
\hline 217 & $4 / 6$ & & \\
\hline 222 & $5 / 6$ & & \\
\hline 223 & $5 / 6$ & & \\
\hline 227 & $0 / 3$ & & \\
\hline 228 & $7 / 10$ & & \\
\hline 230 & $4 / 5$ & & \\
\hline 238 & $3 / 3$ & & \\
\hline 240 & $0 / 1$ & & \\
\hline
\end{tabular}

* Specimens labelled 'UCLA' were prepared by Dr Gitnick, who graciously provided us with some sample material. All other specimens were prepared in our laboratory. Specimens numbered greater than 211 were prepared by Dr Gitnick's method; other specimens were prepared by our previous method, which differed from Gitnick's only in the early processing stages (washing, mincing, and frozen storage).

+ Numbers tested refer to number of different times inoculated into tissue cultures; at each of these times, duplicate or triplicate cultures were inoculated.

$\ddagger 213 \mathrm{~A}$ was prepared from another piece of the specimen designated ' 213 '.

Table 3 Detection of cytopathic effect inducing agents in filtrates of intestinal tissues from non-inflammatory bowel disease subjects

\begin{tabular}{lll}
\hline Specimen* & $\begin{array}{l}\text { No pos/ } \\
\text { nototal }\end{array}$ & Diagnosis \\
\hline Ctrl-UCLA & $(0 / 2$ & Unknown \\
185 & $0 / 2$ & Infarcted bowel \\
188 & $1 / 2$ & Carcinoma \\
218 & $18 / 18$ & Abdominal mass \\
219 & $3 / 4$ & Diverticulosis \\
229 & $6 / 8$ & Colon polyps \\
\hline
\end{tabular}

* Specimens labelled 'UCLA' were prepared by Dr Gitnick, who graciously provided us with some sample material. All other specimens were prepared in our laboratory. Specimens numbered greater than 211 were prepared by Dr Gitnick's method; other specimens were prepared by our previous method, which differed from Gitnick's only in the early processing stages (washing, mincing, and frozen storage).

+ Numbers tested refer to number of different times inoculated into tissue cultures: at each of these times, duplicate or triplicate cultures were inoculated.
Table 4 Passage of cytopathic effect inducing agents in chick embryo fibroblast cultures

\begin{tabular}{|c|c|c|c|}
\hline \multirow[b]{2}{*}{ Specimen* } & \multicolumn{3}{|c|}{ Passage no ${ }^{+}$} \\
\hline & 0 & $l$ & 2 \\
\hline 156 UCLA & $+2 \ddagger$ & \pm & - \\
\hline 202UCLA & +1 & +1 & - \\
\hline $213 \mathrm{~A}$ & +2 & +1 & $\mathrm{nd} \S$ \\
\hline 232 & +2 & \pm & - \\
\hline 243 & +2 & +1 & - \\
\hline Control & - & - & nd \\
\hline Ctrl-UCLA & - & - & nd \\
\hline
\end{tabular}

* All filtrates prepared by Dr Gitnick in his laboratory (designated 'UCLA') or in our laboratory using his methods. The "control' specimen consisted of Hanks' buffered salt solution only.

+ In P1 and P2, parallel cultures were inoculated with P0 samples to demonstrate that the chick embryo fibroblast cultures had not lost sensitivity to cytopathic effect inducing agents.

$\ddagger$ Results were scored as follows: - , no cytopathic effects; \pm , subtle morphological change in less than $25 \%$ of monolayer cells;

+1 , definite cytopathic effect affecting $25 \%$ of monolayer; +2 , cytopathic effect affecting $50 \%$ of monolayer.

$\S$ nd = not done.

generated by heating as even the previously negative filtrate from specimen 214 showed some cytopathic effect inducing activity after heating. Centrifugation experiments were performed by centrifuging an aliquot of filtrate in an Airfuge (Beckman Instruments Inc, Palo Alto, CA) at $100000 \mathrm{rpm}(135000$ $g$ ) for 30 minutes. The supernatants were removed, the pellets were resuspended in an equal volume of Hanks' buffered salt solution, and both fractions were tested for cytopathic effect inducing ability. Cytopathic effect inducing activity was not pelleted to any significant degree. Two-fold dilution in Hanks' buffered salt solution was associated with significant reduction in cytopathic effect inducing ability, whereas increasing the inoculum size was associated with an increased frequency and severity of cytopathic effects.

\section{LACK OF SPECIFICITY OF THE CYTOPATHIC EFFECT TO CHICK EMBRYO FIBROBLAST CULTURES}

An attempt was made to determine whether the cytopathic effect producing ability of tissue filtrates prepared by the third method was specific to chick embryo fibroblasts. We found that the cytopathic effect could be produced in other cell lines, including the mouse adrenal cell line Y-1, in which the cytopathic effect of marked cell rounding and irregularity was markedly different from that induced by extracts of enterotoxigenic $E$ coli. Positive cytopathic effect with this cell line was obtained in eight of $13(62 \%)$ Crohn's disease samples, four of six $(67 \%)$ ulcerative colitis samples, and four of five $(80 \%)$ control samples, and, as 
Table 5 Characterisation of cytopathic effect inducing agent

\begin{tabular}{|c|c|c|c|c|c|c|c|}
\hline Specimens & Untreated & $\begin{array}{l}U V- \\
\text { irradiated }\end{array}$ & Heated & $\begin{array}{l}\text { Genetron } \\
\text { extracted }\end{array}$ & $\begin{array}{l}\text { Airfuge } \\
\text { super }\end{array}$ & $\begin{array}{l}\text { Airfuge } \\
\text { pellet }\end{array}$ & Diluted \\
\hline 212 & $+1^{*}$ & +1 & ndt & nd & nd & nd & - \\
\hline 213 & +2 & +2 & +3 & +1 & - & +1 & +1 \\
\hline 214 & - & - & $+1-+2$ & - & - & - & - \\
\hline 218 & +3 & +3 & $+3-+4$ & +1 & \pm & - & +2 \\
\hline
\end{tabular}

* Results were scored as follows: - , no cytopathic effect; \pm , subtle morphological change affecting less than $25 \%$ of monolayer cells; +1 , definite cytopathic effect affecting $25 \%$ of monolayer; +2 , cytopathic effect affecting $50 \%$ of monolayer; +3 , cytopathic effect affecting $75 \%$ of monolayer; +4 , cytopathic effect affecting entire monolayer.

+ nd $=$ not done.

observed with the chick embryo fibroblasts, the cytopathic effect producing activity could not be passed, was ultraviolet resistant, and was not precipitable.

Similar results were obtained with MRC5 cells, which have proven useful in studies seeking a viral agent for multiple sclerosis, ${ }^{9}$ and with MA104 cells, a monkey kidney line useful in the isolation of human rotavirus. ${ }^{10}$ Thus, our data show that the cytopathic effect producing factor is not strictly specific for chick embryo fibroblast cells.

\section{ELECTRON MICROSCOPIC STUDIES}

Chick embryo fibroblast cultures exhibiting cytopathic effect were examined by electron microscopy using in situ fixation to ensure that specific cells exhibiting cytopathic effect would be examined. In no instance were virus like particles detected.

\section{ANIMAL TRANSMISSION STUDIES}

Thirty seven rabbits were inoculated with tissue filtrates using both the intravenous and intra-ileal routes and were killed after one year. No abnormal histology was noted except for one rabbit which developed an epithelial granuloma in a lymph node adjacent to the terminal ileum. This animal had been inoculated with a filtrate from the same specimen that yielded cytomegalovirus upon inoculation of HEL 638 tissue cultures.

\section{Discussion}

It has long been suspected that the inflammatory bowel diseases, Crohn's disease and ulcerative colitis, may have an infectious aetiology. ${ }^{12}$ This view was supported by reports of successful animal transmission studies; ;1 12 however, attempts to reproduce this work have not always been successful. $^{2}$ Several reports have implicated viruses as aetiologic agents for inflammatory bowel disease. $^{2}$ Gitnick and his associates developed improved tissue culture systems and tissue filtrate preparation methods that provided evidence that a viral agent was specifically associated with Crohn's disease. ${ }^{313}$ Similar experiments associated another viral agent with ulcerative colitis. ${ }^{4}$ In these papers, Gitnick and co-workers reported the passage (in particularly sensitive cell lines) of cytopathic effect inducing agents from Crohn's disease and ulcerative colitis tissue filtrates, the detection by electron microscopy of virus like particles in inoculated cell cultures, and the partial characterisation of the cytopathic effect inducing agents. They concluded that Crohn's disease and ulcerative colitis were associated with serologically distinct but physicochemically similar $(60 \mathrm{~nm}$, heat and ether resistant, RNA containing) viruses. More recently, cytotoxins released from Crohn's disease, ulcerative colitis, and control patients' tissues that may be responsible for the early cytopathic effect observed in chick embryo fibroblast tissue cultures have been described. ${ }^{5}$

We have carried out extensive studies on the possible involvement of viruses in inflammatory bowel disease. Our results do not provide any evidence for the presence of conventional viral agents in tissue filtrates from inflammatory bowel disease patients. Instead, our studies raise questions about the conclusions reached in previous reports that relied on the induction of cytopathic effect in tissue culture systems.

When we used the methods of Gitnick et al, we were unable to identify an inflammatory bowel disease specific cytopathic effect inducing agent that could be passed in tissue culture. Although we did observe cytopathic effect in inoculated cell cultures, it was not specifically associated with inflammatory bowel disease specimens and the cytopathic effect inducing activity could not be passed. Furthermore, we did not detect viruses in Crohn's disease or ulcerative colitis inoculated cultures examined by electron microscopy.

Our work adds another negative report to the 
somewhat contradictory literature of attempts to isolate and characterise viral agents from tissues of inflammatory bowel disease patients. ${ }^{2}$ Whorwell $e t$ $\mathrm{al}^{8}$ reportedly isolated reovirus like agents from Crohn's disease patients; these viruses had physical properties similar to those of the agents described by Gitnick and coworkers. This report, however, was not confirmed by an independent examination of materials obtained from those investigators; instead, mycoplasmas which may induce cytopathic effects in tissue culture cells were discovered. ${ }^{14}$ More recently, Phillpotts et $\mathrm{l}^{15}$ failed to detect viruses in inflammatory bowel disease patient tissues, but reported a non-specific cytopathic effect in cell cultures that they attributed to proteinaceous toxins of various sizes released from inflamed tissues. A subsequent search for persistent viruses in Crohn's disease tissues was also negative. ${ }^{16}$ Morain et al ${ }^{17}$ could not provide any evidence for conventional viruses in Crohn's disease patient tissues; instead they reported a non-transmissible cytopathic effect in cell cultures inoculated with rectal biopsy material, faeces, and leucocyte rich plasma specimens from Crohn's disease patients, ulcerative colitis patients, and patients having other gastrointestinal diseases but with normal rectal mucosa.

Several other studies using alternative approaches to detect viral involvement with inflammatory bowel disease have also been negative, including immunological studies seeking evidence of replicating viruses in Crohn's disease ${ }^{18}$ and nucleic acid hybridisation studies examining the possible relationships of cytomegalovirus ${ }^{19}$ and adenovirus ${ }^{20}$ with inflammatory bowel disease.

Our attempts to more precisely characterise the cytopathic effect inducing agent led us to conclude that it is not a conventional virus. Its resistance to irradiation with ultraviolet light, its nonsedimentability under conditions that would pellet all known conventional viruses, our inability to pass it in tissue culture, and the observed dependence of cytopathic effect development on inoculum size indicated that the cytopathic effect inducing factor was not a self-replicating agent. Instead our results indicate that a cytotoxin is released from intestinal tissues of both inflammatory bowel disease and non-inflammatory bowel disease patients. The partial sensitivity to Genetron extraction suggests that more than one cytopathic effect inducing factor may be involved. Our results agree with those reported by Phillpotts et al ${ }^{15}$ and Morain et al. ${ }^{17}$ Our results are also similar to those of McLaren and Gitnick $^{5}$ with the major exception that we have observed a broader host range for the cytopathic effect inducing factor, including some cell lines (MA-104, Y-1) for which they reported negative results.

While this work provides no evidence in support of a viral association with or aetiology for inflammatory bowel disease, it does not preclude those possibilities. Viruses may be involved in the pathogenesis of inflammatory bowel disease, but these agents may be undetectable by current standard tissue culture techniques - for example, inflammatory bowel diseases may be associated with still unrecognised or with non-cultivatable enteric viruses. One cannot rule out the possibility that a virus is associated with inflammatory bowel disease, but that isolation of the virus may require a number of blind passages under still undetermined appropriate conditions as has been found for human rotaviruses. ${ }^{10}$ Alternatively, viruses may be necessary only at the initial stage of infection and may be unnecessary, at least in conventional infectious forms, for further development of the disease, which might be produced by autoimmune mechanisms. In this case, cultivatable infectious viruses may not even be present in diseased tissues.

This work does, however, indicate that cytotoxic factors are released from intestinal tissue of both inflammatory bowel disease patients and non-inflammatory bowel disease controls. These results emphasise that extensive controls and cautious interpretation of results are necessary in studies seeking evidence of viruses by assaying for the induction of cytopathic effect in tissue cultures.

The authors thank Dr Gary L Gitnick for providing some of his intestinal tissue filtrates for our studies and also for his hospitality during a visit to his laboratory to observe his methods and discuss his work. We also thank Dr David Yawn for his examinations of the rabbits used in the animal transmission experiments, Dr Betty Petrie and $\mathrm{Mr}$ Ed Calomeni for their electron microscopy work, and $\mathrm{Mr}$ Don Thompson for excellent technical assistance. Gratitude is also expressed to the members of the Houston area medical community whose cooperation allowed us to obtain the tissue samples necessary for this study. This work was supported in part by the Veterans Administration, and by grants from the National Foundation for Ileitis and Colitis, the National Institute of Health (AM 25198/01), and the William Stamps Farish Foundation.

\section{References}

1 Thayer WR Jr. Inflammatory bowel disease: where are the frontiers? Med Clin of N Am 1980; 64: 1221-31. 
2 Beeken WL. Transmissible agents in inflammatory bowel disease: 1980. Med Clin of N Am 1980; 64: 1021-35.

3 Gitnick GL, Arthur MH, Shibata I. Cultivation of viral agents from Crohn's disease. Lancet 1976; 2: 215-7.

4 Gitnick GL, Rosen VJ, Arthur MH, Hertweck SA. Evidence for the isolation of a new virus from ulcerative colitis patients. Comparison with virus derived from Crohn's disease. Dig Dis Sci 1979; 24: 609-19.

5 McLaren LC, Gitnick G. Ulcerative colitis and Crohn's disease tissue cytotoxins. Gastroenterology 1982; 82: 1381-8.

6 Vogt P. Focus assay of Rous sarcoma virus. In: Habel $\mathrm{K}$, Salzman NP, eds. Fundamental techniques in virology. New York: Academic Press, 1969: 198-211.

7 Hanks JH, Wallace RE. Relation of oxygen and temperature in the preservation of tissues by refrigeration. Proc Soc Exp Biol Med 1949; 71: 195-200.

8 Whorwell PJ, Beeken WL, Phillips CA, Little PK, Roessner KD. Isolation of rotavirus-like agents from patients with Crohn's disease. Lancet 1977; 1: 1169-71.

9 Melnick JL, Seidel E, Inoue YK, Nishibe Y. Isolation of virus from the spinal fluid of three patients with multiple sclerosis and one with amyotrophic lateral sclerosis. Lancet 1982; 1: 830-3.

10 Sato K, Inaba Y, Shinozaki T, Fujii R, Mafumoto M. Isolation of human rotavirus in cell cultures. Arch Virol 1981; 69: 155-60.

11 Mitchell DN, Rees RJW. Agent transmissible from
Crohn's disease tissue. Lancet 1970; 2: 168-71.

12 Cave DR, Mitchell DN, Brooke BN. Evidence of an agent transmissible from ulcerative colitis tissue. Lancet 1976; 1: 1311-4.

13 Gitnick GL, Rosen VJ. Electron microscopic studies of viral agents in Crohn's disease. Lancet 1976; 2: 217-9.

14 Kapikian AZ, Barile MF, Wyatt RG et al. Mycoplasma contamination in cell culture of Crohn's disease material. Lancet 1979; 1: 466-7.

15 Phillpotts RJ, Hermon-Taylor J, Brooke BN. Virus isolation studies in Crohn's disease: a negative report. Gut 1979; 20: 1057-62.

16 Phillpotts RJ, Hermon-Taylor J, Teich NM, Brooke BN. A search for persistent virus infection in Crohn's disease. Gut 1980; 21: 202-7.

17 Morain CO, Prestage H, Harrison P, Levi AJ, Tyrrell DAJ. Cytopathic effects in cultures inoculated with material from Crohn's disease. Gut 1981; 22: 823-6.

18 Chiba M, McLaren LC, Strickland RG. Immunity to cytopathic agents associated with Crohn's disease: a negative study. Gut 1982; 23: 333-9.

19 Roche JK, Huang ES. Viral DNA in inflammatory bowel disease. CMV-bearing cells as a target for immune-mediated enterocytolysis. Gastroenterology 1977; 72: 228-33.

20 Roche JK, Wold WSM, Sanders PR, Mackey JK, Green M. Chronic inflammatory bowel disease: absence of adenovirus DNA as established by molecular hybridization. Gastroenterology 1981; 81: 853-8. 